\title{
News from Statistical Office
}

\begin{abstract}
Austria
Activities

Austria has fully embarked on the European Community Household Panel (ECHP) and completed wave 1 in 1995 and wave 2 in 1996. In preparation of the Structure of Earnings Survey in 1997, Austria has carried out a pilot survey on this new field of earnings statistics in Austria in 1996. A Conference of the International Association for the Time Use Research with the title "The Use and Value of Time: New Directions in Data Collection and Analysis" was held in the ACSO from 2 to 4 September 1996. From 12 to 14 May 1997 a meeting of price experts within the European Comparison Programme, Group II will take place to discuss purchasing power parities for transition countries in Middle and Eastern Europe.
\end{abstract}

\section{Publications}

A. Franz (ed.) Familienarbeit und Frauen-BIP, article published in Österreichische Studien zur Amtlichen Statistik, volume 3 (1996). ÖSTAT, Kaufkraft in Ost und West-Österreich im europaischen Wirtschaftsvergleich, article published in Beitrage zur Österreichischen Statistik. A. Franz, Family Work and Enlarged GDP: Women's share in enlarged GDP of Austria, 1996 (conference document).

\section{Greece}

Management changes

A new Secretary General of the General Secretariat of the National Statistical Service of Greece has been appointed since the beginning of 1997 , Mr. Nicholas E. Karavitis.

\section{New legislation}

A new legislation was passed by the Parliament, allowing access of the General Secretariat of the National Statistical Service of Greece to administrative sources and administrative archives: Committee of statistical confidentiality.

\section{Hungary}

\section{Management changes}

The Hungarian Central Statistical Office is headed by one President and three Deputy Presidents. During 1996, two new deputy presidents were appointed: Mr. Péter Pukli and Mr. Miklós Balogh.

\section{Publications}

Our publication 1997 Catalogue of publications from the Hungarian Statistical Office is now available. This publication is issued by the Marketing Section of the statistical office. 


\section{Surveys}

During 1996, a Micro Census, based on representative sampling, was conducted. Also, a full scale survey on retail trade and catering was undertaken. The aim of this survey is to establish a retail trade data base.

Web site

We are now available on-line, anywhere in the world, via the Internet in our recently installed site at http:// www.ksh.hu.

\section{Latvia}

\section{Classifications and data collections}

In 1996, the Central Statistical Bureau introduced the Statistical Classification of Economic Activities in the European Community (NACE). The translation of PRODCOM List 1996 and the Community Classification of Products by Activity (CPA) was completed and will be introduced between 1997 and 1998. By then all major EU classifications will be employed in Latvia. To upgrade the quality of the Balance of Payments the CSB started to collect detailed information on enterprises' external accounts. Input-output tables have been introduced for the purpose of following the flows of tangible assets between different branches being vital for upgrading GDP calculations. In January 1997, the consumer price index (CPI) calculations were modified in line with the Classification of Individual Consumption by Purchase (COICOP). This classification meets the requirements posed by Eurostat for the Harmonized Consumer Price Index
(HCPI). The CSB also launched a regular updating of CPI weights on an annual basis following EU requirements. The Cabinet of Ministers approved Regulations on the Agricultural Census in the Year 2000. The CSB began to build the Rural Farm Register that is to be used as the basis for this Census. The CSB launched a set of instruments for retail trade statistics, providing an opportunity to have information since 1996 on retail turnover and the number of employees by trade outlet location. This will enable a regional data breakdown. The CSB created a methodology for surveying personal services, providing aggregated data both at the national and regional level. There were a new set of items on population income included in the Labour Force Survey such as the "major source of income", "the level of wages and salaries". The CSB began to develop the conception of the labour force costs survey.

\section{Cooperation}

In November 1996, the CSB established cooperation activities with Statistics Denmark related to creating an energy data base, comprising all the data available on production, consumption, imports, producers and consumers with various breakdowns. In the second half of 1996, the CSB provided Eurostat's experimental data base with data on international migration (1995 Joint UNSD-Eurostat-ECE Questionnaire on International Migration Statistics). In the reference period, the CSB was preparing the 1997 pilot population census scheduled for March-April 1997. During the reference period, the CSB jointly with EU countries, conducted the time use pilot survey in line with a uniform methodology, and made prepa- 
rations for the population health survey. The first one will provide detailed information on the distribution of working hours and leisure time, while the latter will provide data on people's health condition, physical activities, chronic diseases and consumption of alcohol and tobacco. The time use survey results will be used as a source for estimating the share of hidden economy.

\section{Publications}

Latvia ranked first among the Baltic countries to prepare for publishing environmental statistics, comprising data in conformity with Eurostat recommendations. In the second half of 1996, the following publications were introduced: the Latvian Balance of Payments, Latvian Regions and Major Cities, Labour Force in Latvia (labour force survey results). The CSB created the Home Page for the Internet. The Latvian NSI was the first in the Baltic area to issue the Statistical Yearbook of Latvia on CD-ROM.

\section{Netherlands}

New Central Commission for Statistics

On 6 December 1996, the Netherlands Central Commission for Statistics met for the first time since the law on the CBS/CCS came into force. The Commission's membership was restructured as a consequence of this law. Formerly a body with some 50 members each representing a different institution or segment of society, the Commission now is composed of eleven independent members of high reputa- tion. Professor Rutten, who was for a long time the highest civil servant within the Department of Economic Affairs, has retained the chairmanship. For the first time two members have been drawn from a bank and (formerly) from a large industrial firm to enhance the business point of view. Another remarkable appointment was that of $\mathrm{Mr}$. Chantraine from Eurostat to express the need of good relations between the European Union and national statistical programmes. The Central Commission decides on the multiannual statistical programmes and on the 1997 work programme. These were drafted after intensive bilateral consultations with all organisations concerned, such as the Ministries and the planning offices, that used to be part of the old Commission. For further information on the Commission and on the Statistics Netherlands programme, please contact: $\mathrm{Mr}$ Joris Nobel, Statistics Netherlands, P.O. Box 4000, 2270 JM Voorburg, Netherlands (fax: + 317033759 91; email: jnbl@cbs.nl).

\section{Romania}

\section{Management changes}

Mr. Pavel Wagner was nominated President of the National Commission for Statistics of Romania as of 28 December 1996 replacing Mr. Alexandru Radocea. As professor in statistics at the Academy of Economic Studies in Bucharest, Mr. Wagner has taught generations of young persons the precision of statistical science. As head of the Statistical Institute, he will work towards the integration of the work practices and objectives of "blue collar" and 
"white collar" statisticians so as to better serve the 'generous and noble profession of official statistician.

New projects

The Regional Profiles Exercise (RPE) initiated by Eurostat in 1995 has been completed by the National Commission for Statistics of Romania and the outputs provided to Eurostat. This project is considered to be very important in the frame of Romania joining the European Union. A paper outlining the most characteristic features of the 42 counties and of 8 statistical regions has been prepared by Romanian experts. It is in fact a monograph of the structure and component cells of the state. It is also the first attempt of grouping countries into macro regions. The grouping creates conditions which ensure the representativity of data obtained through sample surveys organized by county groups. They were established on the bases of: proximity of counties; to ensure the representativity of household and enterprise surveys; and, to ensure the social and economic homogeneity by which distinct regions could be defined. 